\title{
Sequence and Series: An Analysis of Mathematical Problem Solving Ability
}

\author{
lyam Maryati \\ Institut Pendidikan Indonesia, iyammaryati@institutpendidikan.ac.id \\ Dila Nurhayati Fadhilah \\ Institut Pendidikan Indonesia, dilanurhayati11@gmail.com
}

\begin{abstract}
This study aims to analyze the level of mathematical problem-solving abilities of students in one of the high schools in Garut City on the material of sequence and series. The method used in this research is the descriptive qualitative research method. The sample in this study was conducted on 5 students in class XI at one of the public high schools in Garut City. The instruments given to the students were 4 questions on the sequence and series material. The conclusion of this study is the mathematical problem-solving ability of class XI high school students in Garut City, seen from the indicators of identifying sufficient data to solve problems and implementing strategies to solve problems, is quite high, but the indicators of making mathematical models are classified as moderate, and checking the correctness of results and answers still relatively low.
\end{abstract}

Keywords: Mathematical Problem Solving Ability, Sequence, and Series

\section{ABSTRAK}

Penelitian ini bertujuan untuk menganalisis tingkat kemampuan pemecahan masalah matematis siswa salah satu SMA di Kabupaten Garut pada materi barisan dan deret. Metode yang digunakan dalam penelitian ini adalah metode penelitian deskriptif kualitatif. Sampel pada penelitian ini dilaksanakan pada 5 orang siswa di kelas XI di salah satu SMA Negeri di Kota Garut. Instrumen yang diberikan pada siswa sebanyak 4 soal pada materi Barisan dan Deret kesimpulan dari penelitian ini adalah berdasarkan: a) Analisis tes kemampuan pemecahan masalah matematis setiap orang siswa secara keseluruhan termasuk kategori sedang; b) Analisis tes kemampuan pemecahan masalah matematis ditinjau dari setiap Indikator secara keseluruhan termasuk kategori sedang; c) Analisis nilai rata-rata hasil analisis tes kemampuan pemecahan masalah matematis ditinjau dari setiap indicator yaitu memahami masalah termasuk kategori sedang, menyusun rencana termasuk kategori sedang, menerapkan rencana termasuk kategori rendah, dan memeriksa kembali termasuk kategori rendah..

Kata Kunci: Kemampuan Pemecahan Masalah Matematis, Barisan dan Deret.

\section{INTRODUCTION}

Mathematics as one of the basic sciences has an important role in accelerating mastery of technology. This is because mathematics is a means of thinking to develop logical, systematic, and critical thinking. Mathematical abilities are instinctive abilities bestowed by God Almighty. Therefore yourself and the environment will affect these mathematical abilities. Mastery of science and technology must be based on mastery of mathematics, because mastery of mathematics is the main key in mastering knowledge (Aulia \& Fitriyani, 2019; Wijayanto et al., 2018).

Mathematical abilities that are expected to be achieved through learning mathematics are listed in the learning objectives set by NCTM, namely basic math abilities which are standards, namely: a) Problem Solving; b) Reasoning and Proof; c) Communication; d) Connections; and e) Representations (NCTM, 2000). Based on the objectives of learning mathematics, students' mathematical problem-solving abilities are very important abilities to be developed from within students. In everyday life, many problems can be solved mathematically.

Problem-solving is a form of individual effort to solve a problem for which there is no definite answer or solution, so it requires irregular thinking (Mawaddah, \& Anisah, 2015; Widodo, 2014; 
Widodo et al., 2018). Students' mistakes in solving questions are related to learning disabilities or imperfect learning abilities. In learning mathematics, mistakes in learning a previous concept will affect understanding the next concept because mathematics is a structured science. Therefore, in the mathematics learning process, not all students always succeed in achieving learning objectives (Natsir et al., 2019).

The percentage of students' ability to understand the problem reached $87.10 \%$ in the very good category, the percentage of students' ability in planning $40.32 \%$ belonged to the bad category, the percentage of the ability to solve problems according to plan $24.19 \%$ belonged to the very poor category, the percentage of students' ability to find back $48.39 \%$ is in a bad category, while the overall average percentage reaches $50 \%$ and is classified in the bad category (Maryati, 2018; Syahputra, 2017). This data shows that the students' mathematical problem-solving abilities are still relatively weak. In addition, the mathematical problem solving ability of students in MAN 2 Bandar Lampung is still low because students have difficulty solving math problems and students rarely ask questions or come up with solutions to ideas (Muhammad, 2015).

Based on observations of the work results of class XI students at a high school in Garut district and the results of interviews with teachers, there are several problems, namely: a) The average score for the Mid-Semester Assessment is still low; b) experiencing confusion when solving non-routine problems; c) students still do not understand the formula or concept that will be used in problem solving. Factors that can affect students cannot solve problems including them; a) lack of understanding of the concept in understanding the material (Pertiwi, 2016; Rahayu et al., 2019; Rismawati \& Komala, 2018), b) less systematic in solving problems (Muhammad, 2015; Septian et al., 2021; Widodo \& Turmudi, 2017).

Analysis of problem-solving abilities carried out in this study is the ability to solve mathematical problems as a process (Polya, 1973). The steps applied in problem solving, namely: namely: a) understanding the problem; b) draw up a plan; c) carry out the plan; d) recheck (Mustafia \& Widodo, 2018; Widodo et al., 2019, 2021). In this study, the problem-solving ability studied in sequence and series material is compulsory mathematics material studied in class XI high school level students. This material is one of the materials that require a variety of resolution methods so that it requires high problem-solving abilities to solve the problems given.

Based on the description above, the purpose of this study was to analyze students' mathematical problem solving abilities in the sequence and series material. Researchers hope that the results of this research can provide solutions in designing good learning so that there are no errors in understanding the concept of sequence and series material (Sopian \& Afriansyah, 2017).

\section{METHOD}

The method used in this research is a qualitative descriptive research method because in this study the objective of this research is to obtain data and information about the students' mathematical understanding ability in solving questions in the material and series. The sample in this study was carried out on 5 students in class XI at one of the public high schools in Garut Regency. The instrument given was a test of mathematical problem-solving abilities on the material of Sequences 
and Series of four questions with four indicators of problem-solving abilities. The data analysis technique in this study was carried out in three stages, namely: 1) data reduction, in this stage the researcher analyzes the data by describing and examining students' answers along with interviews, 2) data presentation, data analysis obtained is presented in a narrative text arrangement, charts or tables along with conclusions, 3 ) the conclusion stage, this stage is the stage of concluding based on data reduction and data analysis that has been carried out (Creswell, 2012).

The instrument used in this study was a test of students' mathematical problem-solving abilities measured using four indicators according to (Polya, 1973). namely: a) understanding the problem; b) draw up a plan; c) carry out the plan; d) recheck. Using a rubric with a score of 0 - 3 based on scoring according to (Sumarmo, 2016). The test instrument consists of four questions and is tested first to determine the level of validity, reliability, difficulty level, and distinguishing power processed using Anates software.

To find the Percentage Value (PV) of mathematical problem solving abilities, a comparison between the obtained ability score (A) to the Maximum Score (MS) is used, or it can be formulated as follows $P \mathrm{~V}=\frac{A}{M S} \times 100 \%$.

In calculating the percentage of student answers qualified into five categories, namely very high if the percentage of mathematical problem solving abilities were obtained between $81 \%-100 \%$, high category if the percentage of mathematical problem solving abilities is obtained between $61 \%$ $80 \%$, moderate category if the percentage of mathematical problem solving abilities is obtained between $41 \%-60 \%$, low category if the percentage of mathematical problem solving abilities is obtained between $21 \%-40 \%$, and the category is very low if the percentage of mathematical problem solving abilities is obtained between $0 \%-20 \%$ (Aisyah, P. N., 2018; Putra, 2017).

\section{RESULT AND DISCUSSION}

The test of students' mathematical problem solving abilities was given as many as four questions in the form of essay questions. After the test questions regarding the students' mathematical problem solving abilities were given to five students, then the test questions were given a score on each question, then the percentage obtained from the score was given and analyzed. The results of the test of students' mathematical problem solving abilities in solving questions on the subject line and series are presented in tables 1,2, and 3 below.

Table 1. Results of the Analysis of the Mathematical Problem Solving Ability Test for each Student

\begin{tabular}{cccccccc}
\hline Students & \multicolumn{4}{c}{$\begin{array}{c}\text { Indicator of Problem } \\
\text { Solving Ability to }\end{array}$} & Total & $\begin{array}{c}\text { Value } \\
\text { Percentage }\end{array}$ & Criteria \\
& 1 & 2 & 3 & 4 & & High \\
S1 & 3 & 2 & 1,5 & 1 & 7,5 & 62,50 & Moderate \\
S2 & 2 & 1,5 & 1 & 1 & 5,5 & 45,83 & Low \\
S3 & 1 & 1 & 1 & 1 & 4 & 33,33 & Moderate \\
S4 & 2 & 2 & 1 & 1 & 6 & 50,00 & Low \\
S5 & 1 & 1 & 1 & 1 & 4 & 33,33 & Moderate \\
& Average & & & 5,4 & 45,00 & \\
\hline
\end{tabular}


Based on table 1 above, the results of students' mathematical problem-solving abilities based on the ability of each student indicate that the mathematical problem-solving ability of undergraduate students obtained a percentage value of $62.50 \%$, including the high category, S2 students' mathematical problem solving abilities obtained a percentage value of $45.83 \%$ including the moderate category, S3 students mathematical problem solving abilities obtained a percentage value of $33.33 \%$, including the low category, Mathematical problem solving abilities of S4 students get a percentage value of $50.00 \%$ including the medium category, and the mathematical problem solving ability of S5 students got a percentage value of $33.33 \%$ which is in the low category, Meanwhile, the average value of the mathematical problem solving ability of all research subjects obtained a percentage value of $45.00 \%$ indicating a moderate category.

Analysis of the results of tests of mathematical problem solving abilities apart from being reviewed based on the ability of each student is also analyzed based on each indicator of problemsolving abilities. Table 2 below shows the results of this analysis.

Table 2. Results of the Analysis of the Mathematical Problem Solving Ability Test in terms of each indicator

\begin{tabular}{lcccccccc}
\hline $\begin{array}{c}\text { Mathematical } \\
\text { Problem Solving }\end{array}$ & \multicolumn{9}{c}{ Student Score } & Total & \multicolumn{2}{l}{ Value } \\
Indicators & 1 & 2 & 3 & 4 & 5 & & Percentage & Criteria \\
\hline Understanding the & 3 & 2 & 1 & 2 & 1 & 9,00 & 75,00 & High \\
Problem & 2 & 1,5 & 1 & 2 & 1 & 7,50 & 62,50 & Moderate \\
Draw up a plan & 1,5 & 1 & 1 & 1 & 1 & 5,50 & 45,83 & Moderate \\
Carry out the plan & 1 & 1 & 1 & 1 & 1 & 5,00 & 41,67 & Moderate \\
Recheck & $\begin{array}{l}1 \\
\text { Average }\end{array}$ & & & & 6,75 & 56,25 & Moderate \\
\hline
\end{tabular}

Based on table 2 above, the results of students' mathematical problem-solving abilities test based on indicators of understanding the problem, namely how students can identify sufficient data to solve problems shows a percentage value of $75.00 \%$ is in the high category. The indicator of preparing a plan is how students can make a mathematical model of a problem and solve the problem obtaining a percentage value of $62.50 \%$ including the high category. The indicator of implementing the plan, namely how students can choose and implement strategies to solve math problems, gets a percentage value of $45.83 \%$ including the moderate category. And the indicator of checking back is how students can check the correctness of the results and the answers get a percentage value of $41.67 \%$ including the medium category. Meanwhile, the average value of all indicators of mathematical problem solving ability shows a percentage value of $56.25 \%$, which is in the medium category.

The average value of the results of the analysis of the problem-solving ability test based on each indicator of problem-solving ability is shown in table 3 below.

Table 3 Analysis of the Average Value of the Analysis Results of the Mathematical Problem Solving Ability Test in terms of each indicator

\begin{tabular}{|c|c|c|c|c|c|c|c|c|}
\hline \multirow{2}{*}{$\begin{array}{l}\text { Mathematical } \\
\text { Problem Solving } \\
\text { Indicators }\end{array}$} & \multicolumn{5}{|c|}{ Student Score } & \multirow{2}{*}{ Average } & \multirow{2}{*}{$\begin{array}{l}\text { Value } \\
\text { Percentage }\end{array}$} & \multirow{2}{*}{ Criteria } \\
\hline & 1 & 2 & 3 & 4 & 5 & & & \\
\hline
\end{tabular}




\begin{tabular}{|c|c|c|c|c|c|c|c|c|}
\hline $\begin{array}{l}\text { Understanding the } \\
\text { Problem }\end{array}$ & 3 & 2 & 1 & 2 & 1 & 1,80 & 60,00 & Moderate \\
\hline Draw up a plan & 2 & 1,5 & 1 & 2 & 1 & 1,50 & 50,00 & Moderate \\
\hline Carry out the plan & 1,5 & 1 & 1 & 1 & 1 & 1,10 & 36,67 & Low \\
\hline Recheck & 1 & 1 & 1 & 1 & 1 & 1,00 & 33,33 & Low \\
\hline
\end{tabular}

Based on table 3 above, the average percentage of students' mathematical problem solving abilities in understanding problems shows a percentage is $60.00 \%$, this means that most students can understand the problem to identify the sufficiency of data in solving the problem. In the indicator of compiling the plan, the average percentage is $50.00 \%$, which means that some students can make a mathematical model of a problem and solve it. The indicator of implementing the plan shows a percentage of $36.67 \%$, which means that most students have not been able to choose and implement strategies to solve math problems. Then the indicator of checking back shows a percentage of $33.33 \%$, which means that most students have not been able to check the correctness of the answer again. The average value of each indicator of students' mathematical problem solving ability, shows that the ability to understand problems and formulate plans has moderate abilities, to carry out plans, and to check the correctness of the answers to the results and the answers are still low.

\section{a. Analysis of the Mathematical Problem Solving Ability Test for each Student}

\section{Mathematical problem solving abilities of $\mathrm{S} 1$ students}

The Mathematical problem solving abilities $\mathbf{S 1}$ students shows high criteria. With the ability of each indicator as follows: a) understand the problem to get a score of 3 , this means that students can write down the information they know and ask the questions correctly to identify the sufficiency of data in solving problems. b) On the indicators of compiling a plan to get a score of 2, this shows that there was an error in planning the procedure for solving the problem in making a mathematical model of a problem and solving it. c) In implementing the plan indicators get a score of 1.5 , this means that students make mistakes in carrying out calculation procedures in choosing and implementing strategies to solve math problems. d) Then on the check again indicator gets a score of 1 , this means that students only check by rereading the questions in checking the correctness of the answer.

Analysis of the mathematical problem solving abilities of undergraduate students, the results of the interviews showed that students experienced confusion in determining the concept to be applied to solve the problem. Most of the material has not been understood correctly, so students still have difficulties in planning procedures, performing calculation procedures, and only checking by re-reading the questions in re-checking the correctness of the answers. Thus the ability to solve mathematical problems of undergraduate students, even though it is a high criterion, is still at a low interval.

\section{Mathematical problem solving abilities of $\mathbf{S} 2$ students}

The mathematical problem solving ability of S2 students shows moderate criteria. With the ability of each indicator as follows: a) understand the problem to get a score of 2, This means that students make mistakes in writing down known information and are asked the questions to identify the adequacy of data in solving problems. b) In the indicator of compiling a plan, it gets a score of 1.5, this shows a little mistake in planning the procedure for solving problems in 
making mathematical models of a problem and solving it. c) On the indicators of implementing the plan to get a score of 1 , this means that students make mistakes in carrying out calculation procedures to solve problems in choosing and implementing strategies to solve mathematical problems. d) In the re-checking indicator, it gets a score of 1 , this means that students only check by re-reading the questions in checking the correctness of the answers.

Analysis of the mathematical problem-solving abilities of postgraduate students, the results of the interviews showed that they experienced a lack of understanding in mastering the material provided by the teacher. Most of the material has not been understood correctly, so students still have difficulty writing down the information that is known and asked about the questions correctly, planning procedures, performing calculation procedures, and just checking by rereading the questions in re-checking the correctness of the answers. Thus the mathematical problem solving abilities of $\mathrm{S} 2$ students are included in moderate criteria.

\section{Mathematical problem solving abilities of S3 students}

The mathematical problem solving ability of $\mathrm{S} 3$ students shows low criteria. With the ability of each indicator as follows: a) understand the problem of obtaining a score of 1 , This means that students make mistakes in writing down known information and are asked the questions to identify the adequacy of data in solving problems. b) On the indicators of compiling a plan to get a score of 1, this shows that there was an error in planning the procedure for solving the problem in making a mathematical model of a problem and solving it. c) On the indicators of implementing the plan to get a score of 1 , this means that students make mistakes in carrying out calculation procedures in choosing and implementing strategies to solve mathematical problems. d) Then on the check again indicator gets a score of 1 , this means that students only check by rereading the questions in checking the correctness of the answer.

Analysis of the mathematical problem-solving abilities of doctoral students, the results of the interview showed that the motivation to understand the material provided by the teacher was very lacking. Most of the material cannot be understood well, so students still have difficulty writing down the information that is known and asked about the questions correctly, planning procedures, performing calculation procedures, and just checking by re-reading the questions in checking the correctness of the answers. Thus the ability of the mathematical problem solving ability of S3 students to solve mathematical problems is considered low criteria.

\section{Mathematical problem solving abilities of $\mathrm{S} 4$ students}

S4 students' mathematical problem solving ability showed moderate criteria. With the ability of each indicator as follows: a) understand the problem to get a score of 2, This means that students make mistakes in writing down known information and are asked the questions to identify the adequacy of data in solving problems. b) On the indicators of compiling a plan to get a score of 2, this shows that there was an error in planning the procedure for solving the problem in making a mathematical model of a problem and solving it. c) On the indicators of implementing the plan to get a score of 1 , this means that students make mistakes in carrying out calculation procedures in choosing and implementing strategies to solve math problems. d) Then on the 
check again indicator gets a score of 1 , this means that students only check by rereading the questions in checking the correctness of the answer.

Analysis of the mathematical problem solving abilities of S4 students. The results of the interview show that most of the material has not been understood correctly, so that students still have difficulty writing down the information that is known and asked about the questions correctly, planning procedures, carrying out calculation procedures, and just checking by rereading the questions in re-checking the correctness of the answers. Thus the ability to solve mathematical problems of S4 students even though it is included in moderate criteria.

\section{Mathematical problem solving abilities of $\mathrm{S} 5$ students}

S5 students' mathematical problem solving ability shows low criteria. With the ability of each indicator as follows: a) understand the problem of obtaining a score of 1 , this means that students make mistakes in writing down known information and are asked the questions to identify the adequacy of the data in solving the problem. b) On the indicators of compiling a plan to get a score of 1 , this shows that there was an error in planning the procedure for solving the problem in making a mathematical model of a problem and solving it. c) On the indicators of implementing the plan to get a score of 1 , this means that students make mistakes in carrying out calculation procedures in choosing and implementing strategies to solve math problems. d) Then on the check again indicator gets a score of 1 , this means that students only check by rereading the questions in checking the correctness of the answer.

Analysis of the mathematical problem-solving abilities of S5 students, the results of the interviews showed that the motivation to understand the material provided by the teacher was very lacking. Most of the material cannot be understood well, so students still have difficulty writing down the information that is known and asked about the questions correctly, planning procedures, carrying out calculation procedures, and just checking by rereading the questions in re-checking the correctness of the answers. Thus the ability of doctoral students to solve mathematical problems is considered a low criterion.

\section{b. Analysis of the Mathematical Problem Solving Ability Test in terms of each indicator}

\section{The Ability to Understand Problems}

The indicator of the ability to understand problems in solving mathematical problems is that students can identify the adequacy of data in solving problems. In this ability undergraduate students can write down the information that is known and asked about the questions correctly, S2 students and S4 students make mistakes in writing down the information that is known and are asked on the questions, S3 and S5 students make mistakes in writing down the information that is known and is asked on the questions. So that students' abilities on this indicator are high criteria. Even though it is included in the high criteria, it is still at the lower interval. The following are examples of student questions and answers in the ability to understand problems. 
Soal 1

Nilai Ujian Matematika siswa kelas XI IPA 9 telah diumumkan, berikut data nilai siswa disajikan dalam sebuah tabel.

\begin{tabular}{|c|c|c|c|c|c|c|c|c|}
\hline $\begin{array}{c}\text { Nama } \\
\text { Siswa }\end{array}$ & \multicolumn{8}{|c|}{ Nilai Ujian Matematika } \\
\hline Siti & Gani & Andi & Melisa & Rahmi & Dika & Candra & Yulia & Neti \\
\hline 96 & 84 & 92 & 76 & 88 & 80 & 72 & 100 & 68 \\
\hline
\end{tabular}

Coba perhatikan data hasil nilai ujian matematika siswa kelas XI IPA 9 seperti yang terlihat pada tabel di atas.

a. Siapakah siswa yang nilai ujiannya tertinggi dan siswa yang nilai ujiannya terendah dalam kelas tersebut?

b. Coba kamu urutkan siswa-siswa tersebut dalam suatu barisan sesuai dengan hasil nilai ujian tiap-tiap siswa dari yang terendah sampai yang tertinggi.

c. Siapakah siswa yang terletak pada urutan ke-5 dan ke-8, dan berapa nilai ujian siswa tersebut?

d. Hitunglah hasil penjumlahan nilai ujian suku ke-15 dan ke-20!

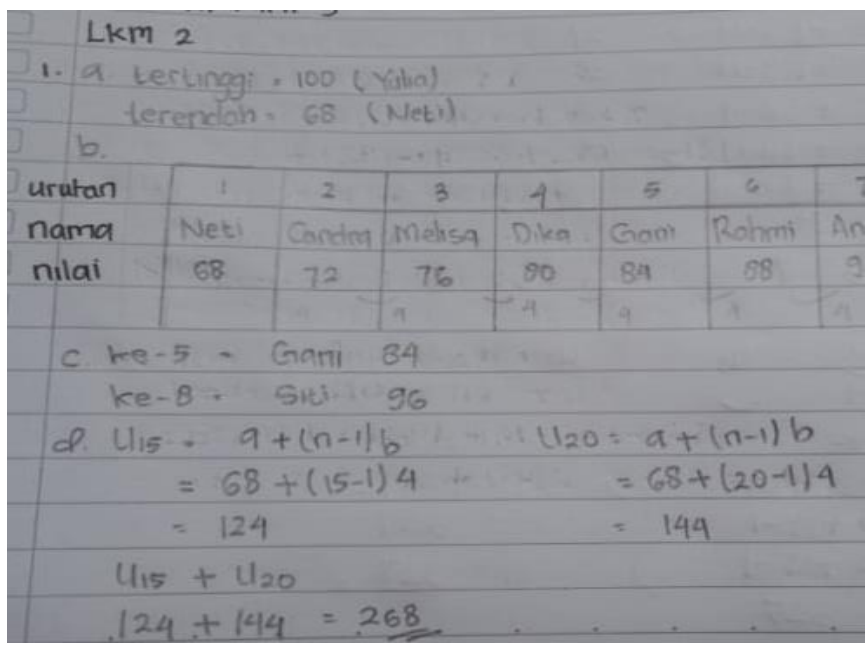

Figure 1. Students' Ability to Understanding Problems

At this stage, students can quite understand the information provided on the questions, but students are not used to writing this information in the form known and asked in solving the questions. So that students do not write it down when doing test questions.

\section{Ability to formulate plans}

The indicator of the ability to make plans in solving mathematical problems is that students can make mathematical models of a problem and solve it. In this ability, S1 and S4 students make a few mistakes in planning problem-solving procedures, S3, and S5 students make mistakes in planning problem-solving procedures. And S2 students make mistakes in planning the procedure to solve problems but the direction of the planning is slightly correct. So that the student's abilities on this indicator are included in moderate criteria. The following are examples of questions and student work results in the ability to plan. 
Soal 2

Diketahui dipojok sebuah ruangan terdapat beberapa kotak yang diletakkan bersusun terdiri dari 4 tingkat susunan.

Perhatikan gambar berikut!

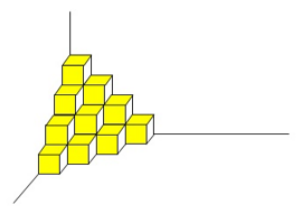

Gambar 2 Susunan Kotak

Berdasarkan gambar di atas, tentukanlah :

a. Berapa jumlah kotak yang terdapat pada lapisan ke-9?

b. Pada lapisan ke berapakah, jika banyak kotak adalah 325 kotak?

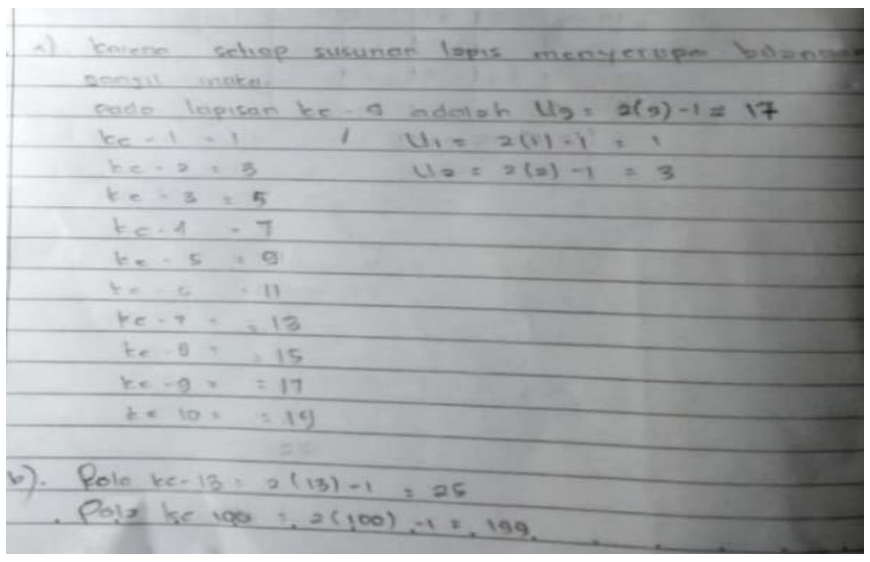

Figure 2. Students' ability to plan

At this stage, students do not understand the questions well, so they are confused in planning the formulas to be used. In addition, it was still found that students wrote wrong formulas and some students did not write formulas but did calculations.

\section{Ability to Implement Plans}

Indicators carry out plans in solving mathematical problems, namely students can choose and apply strategies to solve mathematical problems. In this ability S2, S3, S4, and S5 students have errors in performing the calculation procedure to solve the problem, and undergraduate students make mistakes in the calculation procedure to solve the problem but the direction of the procedure is slightly correct. So that the student's abilities on this indicator are included in moderate criteria. The following are examples of questions and student work results in the ability to implement plans.

\section{Soal 3}

Pertumbuhan virus mengikuti pola barisan geometri. Setiap satu detik virus berkembang biak menjadi 2 kali lipat dari jumlah virus sebelumnya. Jika pada saat permulaan terdapat 5 virus, maka pada detik ke berapa jumlah virus berkembang menjadi 320 virus? 


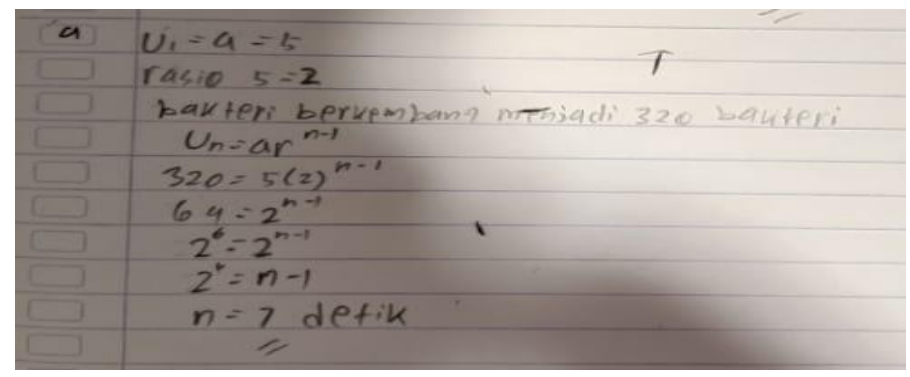

Figure 3. Students' ability to implement plans

At this stage, students do not understand how to implement the plan so that there is an error in the formula to be used. In addition, students were still found to be wrong in completing calculations.

\section{Re-checking ability}

The indicator of the ability to check again in solving mathematical problems is that students can re-check the correctness of the answer. In this ability, all students are only able to doublecheck the correctness of the answers by rereading the questions. So that the student's abilities on this indicator are included in moderate criteria. The following are examples of questions and student work results in the ability to check again.


Figure 4. Student Ability to Re-Check

At this stage students still do not understand how to check again so they only re-read the results of the answers.

\section{c. Analysis of the Average Value of the Analysis Results of the Mathematical Problem Solving Ability Test in terms of each indicator}

Based on the results of the research as a whole, it can be seen that the average score of students' mathematical problem solving abilities as a whole on the line and series material is still moderate. While this value can be seen from the category of students' ability to understand problems and plan problems, including the medium category. And the ability to implement the plan and check the correctness of the answers is in a low category. This causes students to have difficulty solving a problem in the form of story problems, especially in line and series material. This is due to the lack of thoroughness of students in their ability to choose completion strategies so that students make calculations incorrectly. 


\section{CONCLUSION}

Based on the results of the research on the mathematical problem-solving abilities of class $\mathrm{XI}$ students in a high school in Garut City and the discussion that has been described, the conclusions of this study are based on: a) Analysis of the overall mathematical problem solving ability of each student is included in the medium category; b) Analysis of the mathematical problem solving ability test in terms of each indicator as a whole is included in the medium category; c) Analysis of the average value of the results of the analysis of the mathematical problem-solving ability in terms of each indicator, namely understanding the problem, including the medium category, compiling a plan including the medium category, implementing the plan including the low category, and checking again including the low category.

\section{REFERENCES}

Aisyah, P. N., dkk. (2018). Analisis Kemampuan Pemecahan Masalah Matematis Siswa Smp Pada Materi Segiempat Dan Segitiga. Jurnal Pembelajaran Matematika Inovatif. Vol. 1, No. 5.

Aulia, E. T., \& Fitriyani, H. (2019). Implementasi Pendekatan Rigorous Mathematical Thinking (Rmt) Untuk Meningkatkan Kemampuan Pemecahan Masalah Siswa. JOURNAL of MATHEMATICS SCIENCE and EDUCATION, 1(2), 28-42. https://doi.org/10.31540/jmse.v1i2.300

Creswell, J. W. (2012). Educational Research, Planning, Conducting and Evaluating Quantitative and Qualitative Research. (Fourth). USA: Pearson2.

Maryati, I. (2018). Penerapan Model Pembelajaran Berbasis Masalah Pada Materi Pola Bilangan Di Kelas Vii Sekolah Menengah Pertama. Mosharafa: Jurnal Pendidikan Matematika, 7(1), 6374. https://doi.org/10.31980/mosharafa.v7i1.342

Mawaddah, S., \& Anisah, H. (2015). Kemampuan pemecahan masalah matematis siswa pada pembelajaran matematika dengan menggunakag) di smpn model pembelajaran generatif (generative learning) di SMP. EDU-MAT, 3(2).

Muhammad, S. (2015). Pengaruh model pembelajaran creative problem solving berbantuan maple II terhadap kemampuan pemecahan masalah matematis. Al-Jabar: Jurnal Pendidikan Matematika, 6(1), 91-98.

Mustafia, I. D., \& Widodo, S. A. (2018). Problem solving skill: Effectiveness on think pair share with comic. International Journal on Teaching and Learning Mathematics. https://doi.org/10.18860/ijtm.v1i2.7181

Natsir, N., Kadir, K., \& Samparadja, H. (2019). Peningkatan Kemampuan Pemecahan Masalah Matematis Siswa SMP Melalui Pendekatan Saintifik Problem posing. Jurnal Pendidikan Matematika, 9(1), 114. https://doi.org/10.36709/jpm.v9i1.5766

NCTM. (2000). Principles and Standards for School Mathematics. NCTM.

Pertiwi, D. B. (2016). Identifikasi Kemampuan Matematika Siswa dalam Menyelesaikan Masalah Geometri SMP Ditinjau dari Level Fungsi Kognitif Rigorous Mathematical Thinking. Mathedunesa, 3(5), 102-111.

Polya. (1973). How To Solve It. United States of America : Princeton University Press.

Putra, F. G. (2017). Eksperimentasi Pendekatan Kontekstual Berbantuan Hands On Activity (HoA) Terhadap Kemampuan Pemecahan Masalah Matematik. Al-Jabar: Jurnal Pendidikan Matematika, 8(1), 73-80. https://doi.org/10.24042/ajpm.v8i1.1148

Rahayu, N., Karso, K., \& Ramdhani, S. (2019). Peningkatan Kemampuan Pemecahan Masalah Matematis dan Keaktifan Belajar Siswa Melalui Model Pembelajaran LAPS-Heuristik. $\begin{array}{llll}\text { IndoMath: Indonesia } \quad 83 . & \end{array}$ https://doi.org/10.30738/indomath.v2i2.4536

Rismawati, R., \& Komala, E. (2018). Penerapan Pendekatan Pendidikan Matematika Realistik Untuk Meningkatkan Kemampuan Pemecahan Masalah Matematis Siswa. IndoMath: Indonesia Mathematics Education, 1(2), 129. https://doi.org/10.30738/indomath.v1i2.2770

Septian, A., International, S. P.-, \& 2020, U. (2021). The development of calculus teaching materials using geogebra. Proceedings. Uhamka.Ac.ld, 4(1), 1-10.

Sopian, Y. A., \& Afriansyah, E. A. (2017). Kemampuan Proses Pemecahan Masalah Matematis Siswa melalui Model Pembelajaran Creative Problem Solving dan Resource Based Learning (Studi Eksperimen pada Siswa Kelas X SMK Krija Bhakti Utama Limbangan). Jurnal Elemen, 
3(1), 97. https://doi.org/10.29408/jel.v3i1.317

Sumarmo, U. (2016). Pedoman Pemberian Skor Tes Kemampuan Berpikir Matematik dan MPP. Bahan Ajar Mata Kuliah Evaluasi Pembelajaran Matematika Program Magister Ndidikan Matematika STKIP Siliwangi Bandun. [OnIne]. Tersedia: Http://Utari_sumarmo.Dosen.Stkipsiliwangi.Ac.Id/2016/05/Pedoman-Pemberian-Skor-TesKemampuan_berpikir-Matematik-Dan-Mpp.

Syahputra, E. dkk. (2017). Analysis Mathematical Problem Solving Skills of Student of the Grade VIII-2 Junior High School Bilah Hulu Labuhan Batu. Tersedia: International Journal of Novel Research in Education and Learning. [Online]. Www.Noveltyjournals.Com. [27 Mei 2017].

Widodo, S. A., \& Turmudi, T. (2017). Guardian Student Thinking Process in Resolving Issues Divergence. Journal of Education and Learning, 11(4), 432-438.

Widodo, S. A. (2014). Error analysis of guardians student in understanding the problem of divergence. In Proceeding of International Conference on Research, Implementation and Education of Mathematics and Sciences (Pp. 467-472).

Widodo, Sri Adi, Darhim, \& Ikhwanudin, T. (2018). Improving mathematical problem solving skills through visual media Improving mathematical problem solving skills through visual media. Journal of Physics: Conf. Series, 948(1), 1-6. https://doi.org/10.1088/1742-6596/948/1/012004

Widodo, Sri Adi, Ibrahim, I., Hidayat, W., Maarif, S., \& Sulistyowati, F. (2021). Development of Mathematical Problem Solving Tests on Geometry for Junior High School Students. Jurnal Elemen, 7(1), 221-231. https://doi.org/10.29408/jel.v7i1.2973

Widodo, Sri Adi, Istiqomah, Leonard, Nayazik, A., \& Prahmana, R. C. I. (2019). Formal student thinking in mathematical problem-solving. Journal of Physics: Conference Series, 1188, 012087. https://doi.org/10.1088/1742-6596/1188/1/012087

Wijayanto, A. D., Fajriah, S. N., \& Anita, I. W. (2018). Analisis Kemampuan Komunikasi Matematis Siswa Smp Pada Materi Segitiga Dan Segiempat. Jurnal Cendekia: Jurnal Pendidikan Matematika, 2(1), 97-104. https://doi.org/10.31004/cendekia.v2i1.36 